\title{
Effects of the Metacognitive Learning Strategy on the Quality of Prospective Chemistry Teacher's Scientific Explanations
}

\author{
Parlan Parlan \\ Graduate School, Universitas Negeri Malang, Indonesia, parlan.fmipa@um.ac.id
}

\section{Suhadi Ibnu}

Prof., Graduate School, Universitas Negeri Malang, Indonesia, suhadi.ibnu.fmipa@um.ac.id

\section{Sri Rahayu}

Prof., Graduate School, Universitas Negeri Malang, Indonesia, sri.rahayu.fmipa@um.ac.id

\section{Suharti Suharti}

Graduate School, Universitas Negeri Malang, Indonesia, suharti.fmipa@um.ac.id

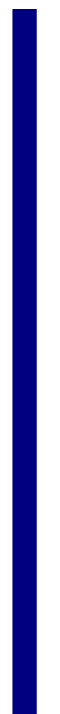

This work is aimed at finding out the effect of the implementation of the metacognitive learning strategy on the quality of prospective chemistry teacher's scientific explanations. This study used a quasi-experimental method with a pretest - post-test control group design. The participants of this research were the students of two classes of Chemistry Education Study Program of a state university in Malang, Indonesia. One class was taught using expository learning (EL) and another class was taught using the metacognitive learning strategy consisting of four stages (preparing, doing, checking, and assessing \& following-up) abbreviated to MS-PDCA. The data of the quality of scientific explanations obtained from the test (reliability $=0.78$ ) were then analysed using descriptive and inferential statistics. The research results showed that 1) the improvement in the quality of scientific explanations for two aspects (technical and conceptual validity) of the students taught using MS-PDCA was higher than that of the students taught using EL. 2) MS-PDCA learning enhanced the skills of constructing scientific explanations in the technical and conceptual validity aspect proportionally. It can be concluded that MS-PDCA can be used effectively in science learning, especially for the study of materials requiring conceptual construction and deep understanding of the relationship among the related concepts.

Keywords: metacognitive strategy, metacognitive ability, scientific explanation, technical aspect, conceptual validity aspect 


\section{INTRODUCTION}

Learning is a mental or psychological activity taking place with active interaction in the environment that creates the changes of understanding (Winkel, 2004). Learning of chemistry is directed to help the students to build their knowledge and thinking skills so that they find the relationship between the concepts of chemistry and are able to use such concepts to explain various chemical phenomena. One of the examples is finding the relationship between molecular structure and macroscopic characteristics of substances in meaningful learning (Cooper, et al., 2013). The facts showed that the learning conducted by teacher in the class is still dominated by conventional learning models (Cook, et al., 2013; Paulson, 1999). Empirical evidence shows that conventional learning cannot assist the students in developing sufficient understanding and conceptual framework of the studied material. For example, the students cannot utilize their understanding of the hydrogen bond to explain the characteristics of substances (Henderleiter, et al., 2001). When the substance melts, it means that the covalent bond is broken, not the intermolecular bonds (Smith \& Nakhleh, 2011).

One of the purposes of science learning is helping out the students to construct the scientific explanations of the phenomena with the right evidence and scientific principles (McNeil \& Krajcik, 2008). The scientific explanation answers three main questions namely what is known (ontology question), how does happen (casual question), and how do you know (epistemic question) (Osborne, et al., 2004). Scientific explanation gives a description of how and why a phenomenon could happen (Chin \& Brown, 2000). The scientific explanation of the natural phenomena often involves invisible things such as atom and force, genetic violence, oxidation, statistics and probability underlying the model, or broad scientific theories (Braaten \& Windschitl, 2011) which demand complex thinking skills (higher order thinking) (Yee et al., 2011).

The central aspect in science education is introducing the scientific explanations to the students to assist them in understanding the primary concepts in science (NRC, 2011). Scientific explanation plays a key role in the document of science education reformation including the Benchmark of Science Literacy (Braaten \& Windschitl, 2011). The first thing that is learned by the students in science learning is how the scientific knowledge is perceived and how it is developed. Research results showed that the learning conducted by the teacher influences the students' ability in constructing scientific explanations (McNeill \& Krajcik, 2008). Through their learning experience, students are expected to be able to construct the scientific explanation of a particular phenomenon supported by the correct evidence and the relevant scientific principles (Sadler, 2004).

The students' ability in constructing scientific explanations is one of the benchmarks of students' understanding of the learned concepts, the relation between concepts, and the implementation in the appropriate context (McNeill \& Krajcik, 2008). The understanding of the learned topic influences the students' ability in effectively using the evidence in making scientific explanations. In constructing the scientific explanation, the ability to choose and use the data is necessary as a proof to support the claim. Generally, the students face difficulty in such complex tasks although they have relatively many 
pedagogical experiences including expertise (McNeill, et al., 2006), especially in choosing the correct evidence supporting the claim (Sandoval \& Millwood, 2005).

Science learning shifts from the learning that requires the students to memorize facts to learning the way to find out and think (Driver, et al., 2000). The development of cognitive science acknowledges the significance of thinking and problem-solving in learning. Learning closely relates to thinking and reasoning. According to Dewey, thinking cannot happen spontaneously but it should be arisen with the problem and question or by giving cognitive conflict (Wong et al., 2001). Dewey's concept of thinking is in line with the results of research of the metacognitive strategy and the importance of teaching the students to think of the thinking process (Kauchak \& Eggen, 1998). According to Marzano (1997), the dimension of thinking are stated with the dimension of learning. In the dimension of learning of Marzano, metacognition is the highest dimension of learning. The dimension of learning has been used as a reference in arranging the learning strategy, planning, assessment, and systematic reformation making (McREL, 1997). A teacher who has a better understanding of metacognition, certain complex understanding of metacognition and metacognitive thinking strategy, teaches the students more metacognitively (Wilson \& Bai, 2010). Effective science learning does not only upgrade the learning but also assists the students to develop the metacognitive ability needed to master the higher science level and to reconstruct the conceptual knowledge and learning strategy (Schraw, et al., 2006). This case shows the significance of enhancing the prospective teacher's metacognitive skill.

Metacognitive learning strategy is one of the alternatives that is proper for science learning. The use of the metacognitive learning strategy enables the students to develop their metacognitive knowledge and awareness. Metacognitive awareness variables have a direct contribution to cognitive variables that are the influence of factors outside the metacognitive awareness variable (Pantiwati, 2017). Both components of metacognition are the importance aspects of science learning. In such learning, the students are expected to describe the object and occurrence, propose questions, construct scientific explanations, test the explanations using suitable scientific ways and communicate the ideas. In this way, the students actively build science understanding by combining scientific knowledge and reasoning (scientific explanations) and thinking skills.

Learning with the metacognition strategy facilitates meaningful learning by 1) relating the new learned topic to prior knowledge (Ausuble, 1968), 2) directing the learning to the goal (goal directed) (Darling-Hammond et al., 2014), 3) centring the learning to the students (active learning) (APA, 1997; Rahman, et al., 2011), 4) supporting the students to construct their understanding by themselves in accordance with the constructivist view (Slavin, 2012), 5) fostering interaction and cooperation (collaborative) between the students (Driver, et al., 1994), and 6) assessing the students' complex ability to know the students' mastery and understanding (Darling-Hammond et al., 2014).

Studies of the implementation of the metacognitive strategy to improve learning have been frequently done such as by Rahman, et al. (2014); Aleven \& Koedinger (2002); Karpicke, et al. (2009); Ku \& Ho (2010); Channa, et al. (2014), and (Yusnaeni, et al., 2017), but studying of metacognitive strategy related to the enhancement of the 
students' ability in constructing scientific explanations has not been sufficiently undertaken. Therefore, it is considered necessary to conduct a research to know the impact of the application of the metacognitive strategy on the development of the quality of students' scientific explanations.

\section{The aim of study}

The aim of this study was to explore whether the metacognitive learning strategy could impact on the quality of prospective chemistry teacher's scientific explanations. Specifically, this study was conducted to find answers to the following questions: 1) Whether the MS-PDCA learning can improve the students' ability to construct scientific explanation namely the technical aspect and conceptual validity aspect; 2) Whether the MS-PDCA learning can enhance the students' ability to construct scientific explanations in the forms of technical aspect and conceptual validity aspect proportionally.

\section{METHOD}

\section{Research Design}

This research used quasi-experimental design with pre-test-post-test control group design model. The research population was all of the second semester students of chemistry education program (prospective chemistry teachers) at a state university in Malang, Indonesia. The research sample consisted of 62 students divided into two classes, which was done by cluster random sampling technique. Based on the pre-test score, both classes have the same initial ability. One class (34 students) as a control class is taught by expository learning (EP) or lecturing and another one class (28 students) as an experimental class that is taught by metacognitive strategies.

The study was conducted for four months, from January to early May 2017. Learning with EP is done in four stages, namely preparation, presentation, correlation, and generalization. In expository learnings, students are passive receivers of a lecturer's explanation (teachers centred). Metacognitive strategies that was employed in this study adapted the strategy developed by Cook et al. (2013), which initially consisted of five stages (preview, attend, review, study, and assess) and then was modified to four steps namely preparing, doing, checking, and assessing \& following-up, abbreviated as PDCA. The description of each phase (syntax) in the metacognitive learning strategy (MSPDCA) is shown in Table 1 . The research design is presented in Table 2.

Table 1

Students' Activity and Lecturer's Help in Learning Using MS-PDCA

\begin{tabular}{|c|c|c|c|}
\hline Phase & Lecturer's Help & Student's Activity & Goal \\
\hline $\begin{array}{l}\text { Phase 1: } \\
\text { Preparing }\end{array}$ & $\begin{array}{l}\text { Facilitating the students to learn } \\
\text { the teaching material and } \\
\text { determine the goal of learning, } \\
\text { identify the key concepts that will } \\
\text { be learned, relevant prior } \\
\text { knowledge and concepts that have } \\
\text { been understood, make a summary } \\
\text { and question list that will be } \\
\text { proposed in the face to face }\end{array}$ & $\begin{array}{l}\text { - Reviewing the teaching } \\
\text { material } \\
\text { - Determining the learning goal } \\
\text { - Determining/choosing the learning } \\
\text { strategy } \\
\text { - Arranging the learning schedule } \\
\text { - Identifying the significant concepts } \\
\text { that will be learned }\end{array}$ & $\begin{array}{l}\text { Preparing the } \\
\text { students to study }\end{array}$ \\
\hline
\end{tabular}




\begin{tabular}{|c|c|c|c|}
\hline Phase & Lecturer's Help & Student's Activity & Goal \\
\hline & activity in the class & $\begin{array}{l}\text { - Identifying the relevant prior } \\
\text { knowledge } \\
\text { - Identifying the essential concepts } \\
\text { that have been understood } \\
\text { - Making the question list that will be } \\
\text { proposed in the face to face activity } \\
\text { in the class }\end{array}$ & \\
\hline $\begin{array}{l}\text { Phase 2: } \\
\text { Doing }\end{array}$ & $\begin{array}{l}\text { Facilitating the students to actively } \\
\text { learn in the class (presentation, } \\
\text { discussion, question and answer, } \\
\text { and making a note/summary of the } \\
\text { lesson) }\end{array}$ & $\begin{array}{l}\text { The students are involved in the } \\
\text { learning activity in the class } \\
\text { (presentation, discussion, question and } \\
\text { answer, proposing questions (why, how, } \\
\text { what is the rationale, what are the } \\
\text { criteria, how if, what is the relation of it } \\
\text { to...how about comparing it to...), } \\
\text { making an important notes). }\end{array}$ & $\begin{array}{l}\text { Facilitating the } \\
\text { students to } \\
\text { construct their } \\
\text { understanding } \\
\text { through active } \\
\text { learning }\end{array}$ \\
\hline $\begin{array}{l}\text { Phase 3: } \\
\text { Checking }\end{array}$ & $\begin{array}{l}\text { - Facilitating the students to } \\
\text { check or monitor their learning } \\
\text { progress } \\
\text { Facilitating the students to reflect } \\
\text { themselves regarding the topic that } \\
\text { has been learned } \\
\text { Helping the students to find out the } \\
\text { difficulties faced during the } \\
\text { learning and the alternative of the } \\
\text { problem-solving }\end{array}$ & $\begin{array}{l}\text { The students check/monitor whether the } \\
\text { planning has been done, assess the } \\
\text { learning, check whether the learning } \\
\text { method has been used effectively, } \\
\text { whether they understand the topic to } \\
\text { teach the other friends? What are the } \\
\text { obstacles and difficulties that they } \\
\text { found in the learning, what should they } \\
\text { do to avoid such difficulties in the next } \\
\text { learning? }\end{array}$ & $\begin{array}{l}\text { Monitoring the } \\
\text { planning, } \\
\text { checking the } \\
\text { learning method } \\
\text { employed, } \\
\text { reflecting on the } \\
\text { learning process } \\
\text { used }\end{array}$ \\
\hline $\begin{array}{l}\text { Phase 4: } \\
\text { Assessing } \\
\text { and } \\
\text { Following } \\
\text {-up }\end{array}$ & $\begin{array}{l}\text { - Facilitating the students to } \\
\text { assess their learning progress and } \\
\text { evaluate whether their planned } \\
\text { learning goal is achieved (if it is } \\
\text { not, what should be done then). } \\
\text { Orienting the students to plan the } \\
\text { next learning activity }\end{array}$ & $\begin{array}{l}\text { The students with their lecturer test the } \\
\text { understanding of the topic that has been } \\
\text { learned. Has the goal of the learning } \\
\text { that has been formulated and agreed } \\
\text { together been achieved? Should the } \\
\text { additional tasks be given to reinforce } \\
\text { the understanding? What will be done } \\
\text { in the next meeting? }\end{array}$ & $\begin{array}{l}\text { Knowing the } \\
\text { achievement of } \\
\text { the learning goal, } \\
\text { giving the } \\
\text { feedback and } \\
\text { following up with } \\
\text { the learning } \\
\text { outcome }\end{array}$ \\
\hline
\end{tabular}

Table 2

Scheme of Research Design (adapted from Creswell, 2007)

\begin{tabular}{llll}
\hline Group & Pre-test & Treatment & Post-test \\
\hline Control & $\mathrm{O}$ & EP & $\mathrm{O}$ \\
Experiment & $\mathrm{O}$ & SM-PDCA & $\mathrm{O}$ \\
\hline
\end{tabular}

\section{Note:}

$\mathrm{O}$ : Observation (pre-test and post-test of molecular structure and chemical properties relationships)

EP : Learning using expository/lecturing

MS-PDCA : Learning using metacognitive strategy (MS-PDCA)

\section{Data Collection and Analysis}

The data were collected from the score of the pre-test and post-tests of students' scientific explanations. Pre-test was conducted in the beginning of the research, in the third week of January and post-tests were held in the first week of May 2017. A total of 5 test items was used on the pre-test and post-tests. The test was made by researchers 
and validated by 3 chemical education experts. Type the test was essay which ask the students give answers in the form of scientific explanation. Based on the pilot project conducted with 92 , it was revealed that all the items were valid $(p<0.05)$ with the coefficient Cronbach's Alpha of 0.78. It can be concluded that the test is feasible to use (Morgan, et al., 2004). In addition, a questionnaire was also used to find out the students' responses to learning with metacognitive strategies.

The scientific explanation was assessed in two aspects namely the technical and conceptual validity aspects. The technical aspect was assessed based on the completeness of the components of Toulmin's reasoning, while the aspect of conceptual validity was assessed based on the truth and appropriateness with the concepts of chemistry, laws, theories, and principles in scientific explanations. The assessment of the students' scientific explanations was undertaken using the rubric developed by Sutopo and Waldrip (2014). Scoring of the scientific explanations from the technical aspect consisted of five levels (L-0, L-1, L-2, L-3, and L-4) and the conceptual validity aspect consisted of four levels (L-0, L-1, L-2, and L-3). Both rubrics are presented in Table 3 and Table 4.

Table 3

Rubric to code the technical aspect of student's scientific explanations quality

\begin{tabular}{|c|c|c|c|}
\hline Category & $\begin{array}{c}\text { Score/ } \\
\text { level }\end{array}$ & Description/indicator & More detailed description \\
\hline $\begin{array}{l}\text { Inductive/ } \\
\text { deductive } \\
\text { rule-based } \\
\text { explanation }\end{array}$ & 4 & $\begin{array}{l}\text { Claim is backed up by } \\
\text { generalized } \\
\text { relationship, } \\
\text { principle, theory, or } \\
\text { law. }\end{array}$ & $\begin{array}{l}\text { The rationale consists of a comprehensive } \\
\text { data analyses supported by a principle, } \\
\text { theory, law, or definition that are relevant to } \\
\text { the data and problem being solved. The } \\
\text { scientific correctness of the theory, law, etc., } \\
\text { used in this reason is not important. }\end{array}$ \\
\hline $\begin{array}{l}\text { Evidence- } \\
\text { based } \\
\text { explanation }\end{array}$ & 3 & $\begin{array}{l}\text { Claim is backed up by } \\
\text { evidence, including } \\
\text { analogy and analysis } \\
\text { of data }\end{array}$ & $\begin{array}{l}\text { The rationale has considered an amount of } \\
\text { data (including implicit data) and applied a } \\
\text { relevant data analyses, but not enough to } \\
\text { solve the problem correctly. }\end{array}$ \\
\hline $\begin{array}{l}\text { Data-based } \\
\text { explanation }\end{array}$ & 2 & $\begin{array}{l}\text { Claim is backed up by } \\
\text { data. }\end{array}$ & $\begin{array}{l}\text { The rationale relies on limited data or the } \\
\text { surface feature of the problem. }\end{array}$ \\
\hline $\begin{array}{l}\text { No } \\
\text { explanation }\end{array}$ & 1 & $\begin{array}{l}\text { Claim is not backed } \\
\text { up, or the backup is } \\
\text { pseudo, or tautology }\end{array}$ & $\begin{array}{l}\text { The rationale, if any, is merely a restatement } \\
\text { of the claim (response) or not clearly related } \\
\text { to the problem nor clear in meaning. }\end{array}$ \\
\hline Unidentified & 0 & No response & Student's answer sheet is blank. \\
\hline
\end{tabular}


Table 4

Rubric to code the conceptual validity aspect of student's scientific explanations

\begin{tabular}{lll}
\hline \multicolumn{1}{c}{ Category } & Score/level & Definition \\
Fully valid & 3 & Claim is correct and follows from the relevant and correct backup \\
Partially valid & 2 & $\begin{array}{l}\text { C Claim is correct but the backup is not fully appropriate } \\
\text { (incomplete or partially irrelevant), or }\end{array}$ \\
Invalid & 1 & $\begin{array}{l}\text { Claim is incorrect since it follows from an inappropriate } \\
\text { backup }\end{array}$ \\
backup or does not logically follow from backup, or \\
Unidentified
\end{tabular}

The assessment of students' scientific explanations were carried out by two persons namely the researcher and the lecturer of organic chemistry in the Chemistry Department at the State University of Malang, Indonesia. The equality of the appraisal results of the assessment by both persons were $82.7 \%$ with the Kappa value of $0.687(p<0.05)$ for the technical aspect and $79.3 \%$ of $0.635(p<0.05)$ for the conceptual validity aspect.

To know the difference in the improvement of the scientific explanation in the EL and MS-PDCA classes, the analysis was done by testing the difference in the independent sample. The data analysis was conducted using SPSS for Windows.

To know the improvement of scientific explanation from the pre-test to the post-test, the analysis was executed using average normalized-gain scores (Bao, 2006; and Cohen's d-effect size (Morgan et al., 2004). The normalized gain score (N-gain) was calculated using the equation:

$$
<\mathbf{g}>=\frac{\text { posttest }- \text { pretest }}{\text { maximum score }- \text { pretest }}
$$

The interpretation of the value $\langle g\rangle$ was based on the category given by Hake (1998) regarding the amount of effect of instruction, that is high if $<\mathrm{g}>\geq 0.65$, upper-middle if $0.45 \square<\mathrm{g}><0.65$, lower-middle if $0.25 \square<\mathrm{g}>0.45$, and low if $<\mathrm{g}><0.25$.

Cohen's $d$-effect size was computed using the equation:

$$
\begin{gathered}
\text { Cohen's } d=\left(M_{2}-M_{1}\right) / S D_{\text {pooled }} \\
S D_{\text {pooled }}=\sqrt{ }\left(\left(S D_{1}{ }^{2}+S D_{2}{ }^{2}\right) / 2\right)
\end{gathered}
$$

The interpretation of Cohen's was done based on the criteria of $d$ (Morgan et al., 2004) with the interpretation which is much larger than typical if $d \geq 0.90$, larger than typical if $0.70 \leq d<0.90$, typical or medium if $0.40 \leq d<0.70$, and smaller than typical if $d<$ 0.40 .

\section{FINDINGS}

The tested hypothesis in this research are 1) the enhancement of the students' ability to construct the scientific explanations from the technical aspect in the MS-PDCA class is 
higher than that of the EL class 2) the enhancement of the students' ability to construct scientific explanations from the conceptual validity aspect of MS-PDCA class is higher compared to that of the EL class.

The summary of the results of the normality test and the variance homogeneity test of the students' scientific explanations data is presented in Table 5.

Table 5

The Summary of the Results of the Normality Test and the Variance Homogeneity Test of the Scientific Explanation Score

\begin{tabular}{llllll}
\hline \multirow{2}{*}{ Scientific Explanation } & \multicolumn{2}{l}{ Normality (Kolmogorov-Smirnov ${ }^{\text {a) }}$} & \multicolumn{2}{c}{ Variance Homogeneity } \\
\cline { 2 - 6 } & & $\mathrm{N}$ & Sig. & Lavene Statistic & Sig. \\
\hline \multirow{2}{*}{ Technique } & Pre-test & 62 & 0.000 & 1.555 & 0.217 \\
\cline { 2 - 6 } & Post-test & 62 & 0.002 & 2.678 & 0.107 \\
\hline \multirow{2}{*}{$\begin{array}{l}\text { Conceptual } \\
\text { validity }\end{array}$} & Pre-test & 62 & 0.000 & 2.042 & 0.158 \\
\cline { 2 - 6 } & Post-test & 62 & 0.000 & 0.998 & 0.322 \\
\hline
\end{tabular}

Based on Table 5 , the data of students' scientific explanations are not normally distributed (sig. < 0.05) and have a homogeny variance (sig. > 0.05). Based on the results, the test of difference was done using non-parametric statistics of Mann-Whitney. The analysis results of the difference test of the data of scientific explanation of the EL class and the MS-PDCA class using Mann-Whitney are presented in Table 6.

Table 6

The Analysis Results of the Difference in the Test of Scientific Explanation Data in the EL Class and the MS-PDCA Class Using Mann-Whitney

\begin{tabular}{llll}
\hline Data & Aspect of Scientific Explanation & Mann-Whitney U & Asymp. Sig. (2-tailed) \\
\hline \multirow{2}{*}{ Pre-test } & Technique & 378.000 & 0.160 \\
\cline { 2 - 4 } & Conceptual validity & 452.500 & 0.731 \\
\hline \multirow{2}{*}{ Post-test } & Technique & 45.500 & 0.000 \\
\cline { 2 - 4 } & Conceptual validity & 58.000 & 0.000 \\
\hline
\end{tabular}

Table 6 shows that the results of the difference test of the pre-test data of scientific explanation using Mann-Whitney yielded the significant value of $p=0.160$ (sig > 0.05) for technical aspect and $p=0.731$ (sig $>0.05$ ) for conceptual validity aspect. This means that there was no difference of the initial students' ability in constructing the scientific explanations in the EL class and the MS-PDCA class for both aspects of scientific explanations. The results of difference test of post-test data using Mann-Whitney yielded the significant value of $p=0.000$ ( $\mathrm{sig}<0.05$ ) for technical aspect and $p=0.000$ ( $\mathrm{sig}<$ 0.05 ) for conceptual validity aspect. This means that there was a difference of students' ability in constructing the scientific explanations of the EL class and the MS-PDCA class for both aspects of scientific explanations after learning. The improvement of the students' ability to construct scientific explanations in the MS-PDCA class was significantly higher than the improvement of the students' ability to construct scientific explanations in the EL class for both aspects of scientific explanations. Therefore, it can be concluded that both hypotheses can be accepted.

The data of the mean of N-Gain also supports the conclusion. The averages of N-Gain class taught using MS-PDCA were higher than the EL class namely 0.83 for the MS- 
PDCA class that was higher than 0.31 for the EL class for technical aspect. For the conceptual validity aspect in the MS-PDCA class, the average was 0.79 which was higher than 0.27 for the EL class.

The effectiveness level of EL and MS-PDCA learning in upgrading the students' ability to construct the scientific explanations is also indicated from the value of the effect size as presented in Table 7.

Table 7

The Value of Effect-size

\begin{tabular}{llll}
\hline Class & Aspect of Scientific Explanations & Effect-size & Interpretation \\
\hline \multirow{2}{*}{ EL } & Technique & 0.875 & larger than typical \\
\cline { 2 - 4 } & Conceptual validity & 0.713 & larger than typical \\
\hline \multirow{2}{*}{ MS- } & Technique & 3.686 & much larger than typical \\
\cline { 2 - 4 } PDCA & Conceptual validity & 2.296 & much larger than typical \\
\hline
\end{tabular}

Based on the criteria mentioned by Morgan et al. (2004), the value of the effect size for both aspects of the scientific explanations of the students taught using EL was lower (larger than typical) than the scientific explanation of the students taught using MSPDCA (much larger than typical).

The change of the distribution of the students' scientific explanations for technical and conceptual validity aspects on pre-test and post-test in the EL class are shown by the cross tabulation in Table 8 and Table 9.

Table 8

Cross Tabulation of Pre-Test and Post-Test of Students' Scientific Explanation for Technical Aspect in the EL Class

\begin{tabular}{lllllllll}
\hline & & \multicolumn{2}{l}{ PRE-TEST } & & \multicolumn{2}{c}{ Total Post-test } \\
\cline { 2 - 8 } & L-0 & L-1 & L-2 & L-3 & L-4 & Total & $\%$ \\
\hline \multirow{3}{*}{ POST- } & L-1 & 2 & 4 & 4 & 0 & 0 & 10 & 5.9 \\
TEST & L-2 & 13 & 23 & 55 & 4 & 0 & 95 & 55.9 \\
& L-3 & 3 & 2 & 34 & 7 & 2 & 48 & 28.2 \\
& L-4 & 1 & 4 & 12 & 0 & 0 & 17 & 10.0 \\
\hline Total of & Total & 19 & 33 & 105 & 11 & 2 & 170 & 100.0 \\
\cline { 2 - 9 } Pre-test & $\%$ & 11.2 & 19.4 & 61.8 & 6.5 & 1.2 & 100.0 & \\
\hline
\end{tabular}

Table 9

Cross Tabulation of Pre-Test and Post-Test of Students' Scientific Explanation for Conceptual Validity Aspect in the EL Class

\begin{tabular}{llllllll}
\hline & & \multicolumn{2}{l}{ PRE-TEST } & & \multicolumn{2}{l}{ Total of Post-test } \\
\cline { 2 - 7 } & & L-0 & L-1 & L-2 & L-3 & Total & $\%$ \\
\hline \multirow{3}{*}{ POST- } & L-0 & 0 & 2 & 0 & 0 & 2 & 1.2 \\
TEST & L-1 & 4 & 36 & 15 & 0 & 55 & 32.4 \\
& L-2 & 1 & 57 & 27 & 6 & 91 & 53.5 \\
& L-3 & 1 & 16 & 5 & 0 & 22 & 12.9 \\
\hline Total of & Total & 6 & 111 & 47 & 6 & 170 & 100.0 \\
Pre-test & $\%$ & 3.5 & 65.3 & 27.6 & 3.5 & 100.0 & \\
\hline
\end{tabular}


Based on Table 8 and Table 9, the proportion of the quality of students' scientific explanations in the EL class that is in the highest two levels increased from $\sim 8 \%$ on pretest to $\sim 38 \%$ on post-test for technical aspect, while for conceptual validity aspect, the students who were in the highest level enhanced from $\sim 3 \%$ to $\sim 13 \%$. Based on Table 8 , there were $66(38.8 \%)$ scientific explanations of students who had similar score before learning (pre-test) and after learning (post-test) for the technical aspect and $63(37.1 \%)$ scientific explanations for the conceptual validity aspect (Table 9). It means that the proportion of the students' scientific explanations which were the same between the pretest and the post-test was relatively big (close to $40 \%$ ).

The changes of the distribution of the students' scientific explanations in the MS-PDCA class for technical aspect and conceptual validity aspect on pre-test and post-test are presented in Table 10 and Table 11.

Table 10

Cross Tabulation of Pre-Test and Post-Test of Students' Scientific Explanation for Technical Aspect in the MS-PDCA Class

\begin{tabular}{llllllll}
\hline & & \multicolumn{2}{l}{ PRE-TEST } & & \multicolumn{2}{c}{ Total of Post-test } \\
\cline { 2 - 7 } & & L-0 & L-1 & L-2 & L-3 & Total & $\%$ \\
\hline \multirow{3}{*}{ POST- } & L-1 & 0 & 1 & 0 & 0 & 1 & 0.7 \\
TEST & L-2 & 1 & 4 & 1 & 0 & 6 & 4.3 \\
& L-3 & 3 & 20 & 24 & 1 & 48 & 34.3 \\
& L-4 & 4 & 28 & 51 & 2 & 85 & 60.7 \\
\hline Total of & Total & 8 & 53 & 76 & 3 & 140 & 100.0 \\
\cline { 2 - 8 } Pre-test & $\%$ & 5.7 & 37.9 & 54.3 & 2.1 & 100.0 & \\
\hline
\end{tabular}

Table 11

Cross Tabulation of Pre-Test and Post-Test of Students' Scientific Explanation for Conceptual Validity Aspect in the MS-PDCA Class

\begin{tabular}{llllllll}
\hline & & \multicolumn{2}{l}{ PRE-TEST } & & \multicolumn{2}{c}{ Total of Post-test } \\
\cline { 2 - 7 } & & L-0 & L-1 & L-2 & L-3 & Total & $\%$ \\
\hline \multirow{2}{*}{ POST- } & L-1 & 0 & 5 & 0 & 0 & 5 & 3.6 \\
TEST & L-2 & 2 & 25 & 13 & 0 & 40 & 28.6 \\
& L-3 & 1 & 61 & 31 & 2 & 95 & 67.9 \\
\hline \multirow{2}{*}{ Total of } & Total & 3 & 91 & 44 & 2 & 140 & 100.0 \\
\cline { 2 - 7 } Pre-test & $\%$ & 2.1 & 65.0 & 31.4 & 1.4 & 100.0 & \\
\hline
\end{tabular}

Based on Table 10 and Table 11, it is known that the proportion of the students' sceintific explanation in the MS-PDCA class in both highest levels increased from $~ 2 \%$ on pre-test to $\sim 95 \%$ on post-test for technical aspect, while the proportion of the students's scientific explanation in the highest level enhanced from $\sim 1,5 \%$ on pre-test to $\sim 68 \% \%$ on post-test for the conceptual validity aspect. From Table 10, it is also known that only three $(2.1 \%)$ of students' scientific explanations that have a similar score between pre-test and post-test for the technical aspect and $20(14.3 \%)$ students' scientific explanations for the conceptual validity aspect (Table 11). Based on such data, it can be concluded that the improvement of the students' ability to construct scientific explanations in the MS-PDCA class was higher than that in the EL class for both 
technical and conceptual validity aspects. The MS-PDCA strategy had the higher effectiveness in upgrading the students' ability to construct the scientific explanations. The analysis results also supported the previous conclusion that the MS-PDCA learning increases the students' ability to construct scientific explanations.

The average N-gain $(<\mathrm{g}>)$ score (Hake, 2002) and the percentage $[(\overline{\mathrm{g}}-\mathrm{g}) / \mathrm{g}](\mathrm{Bao}, 2006)$ of the students' scientific explanations of MS-PDCA class for technical and conceptual validity aspects are presented in Table 12.

Table 12

The N-Gain average, Mean of N-Gain <g> Score, and Percentage $[(\bar{g}-g) / g]$ of Students' Scientific Explanation in the MS-PDCA Class

\begin{tabular}{lccc}
\hline Scientific Explanation & $\begin{array}{c}\mathrm{N}-\text { Gain average } \\
\langle\overline{\mathrm{g}}>\end{array}$ & $\begin{array}{c}\text { Mean of N-Gain } \\
\langle\mathrm{g}>\end{array}$ & {$[(\overline{\mathrm{g}}-\mathrm{g}) / \mathrm{g}] \%$} \\
\hline Technical Aspect & 0.83 & 0.82 & 1.23 \\
Conceptual Validity Aspect & 0.79 & 0.68 & 16.18 \\
\hline
\end{tabular}

Based on the criteria given by (Hake, 1998), the scores are categorized as high for technical and conceptual validity aspects. The combination of both parameters (the effect size and mean of N-gain) can be concluded that the MS-PDCA has high effectiveness to improve the students' ability to construct scientific explanations for both technical and conceptual validity aspects.

If the mean of $\mathrm{N}$-gain $(\langle\mathrm{g}\rangle)$ in Table 12 is compared with the $\langle\overline{\mathrm{g}}\rangle$ score, the $\langle\overline{\mathrm{g}}\rangle$ score was a little bit higher than the $\langle\mathrm{g}\rangle$ score of its pair, namely the $\langle\overline{\mathrm{g}}\rangle$ score for technical aspect which was 0.83 while the $\langle\mathrm{g}\rangle$ score was 0.82 , while the $\langle\bar{g}\rangle$ score for conceptual validity aspect was 0.79 while the $\langle\mathrm{g}\rangle$ score was 0.68 . Based on the $(\overline{\mathrm{g}}-\mathrm{g}) / \mathrm{g}$ score in Table 12, it can be concluded that the shift of the class distribution from the pre-test to the post-test is categorized in the normal-constant shift for technical and conceptual validity aspects (Bao, 2006). It means that the students used the learning and teaching process proportionally to upgrade the ability to construct scientific explanations for technical and conceptual validity aspects. The MS-PDCA facilitates to develop the students' ability to construct scientific explanations proportionally for technical and conceptual validity aspects.

\section{DISCUSSION}

The results of data analysis showed that the improvement of the students' ability to construct scientific explanations in the MS-PDCA class was higher than that in the EL class. In other words, MS-PDCA positively influenced the students' ability to construct scientific explanations. In the EL class, the students passively accepted information while the lecturer dominantly delivered the information and explanations. This kind of learning force the students to study by memorizing (rote learning), inhibiting the development of critical thinking and meaningful learning as well as resulting in shallow thinking (Schrock \& Benko, 2015; Paulson, 1999). The students tended to understand every concept separately and to less understand the connection between the concepts so that their ability to construct the scientific explanation was low. On the other hand, in 
MS-PDCA learning, since the very first time, the students were encouraged to prepare themselves to learn, arrange the lesson plan, monitor and evaluate the learning, as well as be actively be involved in the learning to create a meaningful learning process (Ausuble, 1968; APA, 1997; Rahman, et al., 2011; Slavin, 2012).

Scientific explanation is closely related to cognitive process (Keil, 2006); the higher the students' metacognitive ability, the better their scientific explanations. Metacognition describes the thinking skill about one's thinking (Shannon, 2008). In MS-PDCA learning, the students are facilitated to enhance their metacognitive ability by: determining the learning goal, identifying the prior knowledge, choosing/planning the relevant learning strategy, being actively involved in learning, monitoring the understanding and learning strategy, as well as evaluating their learning (Collins, 2011; Jackson, 2004).

The increase in metacognitive knowledge (declarative, procedural, and conditional) helps the improvement of students' understanding. When the students faced a phenomenon, they could identify the related concepts, find the relationship between the concepts and why such concepts are linked to each other. The enhancement of the understanding is in line with the improvement of the ability to construct scientific explanations (Mcneill \& Krajcik, 2006). The improvement of metacognitive ability indicates the increase in the ability to plan and select the learning strategy, monitor the understanding and learning strategy, and evaluate their understanding. The learners who have metacognitive ability are better in forming a better understanding (Tali \& Dar, 2014).

In the MS-PDCA learning, the students were actively involved in the learning through group discussions. In those discussions, each student was free to deliver their opinion and argumentation, debate, and test the understanding. The students' understanding is formed through social interaction with other students, lecturers, and the learning source (Driver, et al., 1994), and the media that culturally form their understanding (Zhou \& Brown, 2014). The lecture's role in learning is providing a learning environment enabling the students to construct their understanding (Schneider \& Stern, 2010). When the students asked a question, the lecturer did not directly answer, but facilitated the students to think and find out the answer by themselves.

The improvement of students' ability to construct scientific explanations shows that they could apply their knowledge and understanding in a new situation. The ability to implement the understanding in a new situation is in line with the understanding. The metacognitive learning facilitates the students to learn with understanding (Tali \& Dar, 2014).

Based on the students' response in the MS-PDCA class to the questionnaire, it is known that 1) all students felt that the tasks given before learning helped to prepare themselves to the learning well, 2) $93 \%$ of the students said that the learning phases in the MSPDCA they passed enabled them to understand the topic well, 3) all students felt that the lecturer gave the opportunity to monitor their understanding, and 4) 96\% of the students stated that the evaluation provided at the end of learning assisted them to know their understanding of the topic that had been learned. 


\section{CONCLUSION}

Based on the research results, it can be concluded that 1) MS-PDCA learning improves the students' ability to construct the scientific explanation for two aspects of scientific explanation namely technical aspect and conceptual validity aspect; 2) MS-PDCA learning enhances the students' ability to construct the scientific explanations for technical aspect and conceptual validity aspect proportionally; and 3) MS-PDCA learning enables the students to learn meaningfully through the activities of preparing to learn, choosing and planning the learning strategy, being actively involved in the learning, monitoring the understanding, and evaluating the learning. The findings of this study have some implications for teachers to make efforts to improve their students' ability in constructing scientific explanations. This can be done by selecting a learning model that has a potential to facilitate critical and meaningful learning.

\section{REFERENCES}

Aleven, V. A. W. M. M., \& Koedinger, K. R. (2002). An effective metacognitive strategy: Learning by doing and explaining with a computer-based Cognitive Tutor. Cognitive Science, 26(2), 147-179.

American Psychological Association, APA. (1997). Learner-Centred Psychological Principles: A Framework for School Reform \& Redesign. 1-7.

Ausubel, D. P. (1968.) Educational Psychology: A Cognitive View. New York and Toronto: Holt, Rinehart and Winston.

Bao, L. (2006). Theoretical comparisons of average normalized gain calculations. American Journal of Physics, 74(10), 917-922.

Braaten, M., \& Windschitl, M. (2011). Working toward a stronger conceptualization of scientific explanation for science education. Science Education, 95(4), 639-669.

Channa, M. A., Nordin, Z. S., Siming, I. A., Chandio, A. A., \& Koondher, M. A. (2014). Developing Reading Comprehension through Metacognitive Strategies: A Review of Previous Studies. English Language Teaching, 8(8), 181-187.

Chin, C. \& Brown, D.E. (2000). Learning in Science: A Comparison of Deep and Surface Approaches. Journal of Research in Science Teaching. 37 (2), 109-138.

Collins, T.A. 2011. Science Inquiry as Knowledge Transformation: Investigating Metacognitive and Self-regulation Strategies to Assist Students in Writing about Scientific Inquiry Tasks. A Dissertation: Oregon State University.

Cook, E., Kennedy, E., \& McGuire, S. Y. (2013). Effect of Teaching Metacognitive Learning Strategies on Performance in General Chemistry Courses. Journal of Chemical Education, 90(2), 961-967.

Cooper, M. M., Corley, L. M., \& Underwood, S. M. (2013). An investigation of college chemistry students' understanding of structure-property relationships. Journal of Research in Science Teaching, 50(6), 699-721. 
Creswell, J.W. and Clark, V.L.P. (2007). Designing and conducting mixed methods research. Thousand Oaks, CA: Sage Publications.

Darling-hammond, D. L., Austin, K., Cheung, M., Martin, D., Contributions, W., Brigid, F., Questions, K. (2014). Session 9 Thinking About Thinking: Metacognition I . Key Questions and Learning Objectives II . Session Overview. The Learning Classroom, 157-172.

Driver, Roselind; Asoko, Hilary; Leach, J. M. S. P. (1994). The Nature of Scientific Knowledge. Educational Rechearcher, 23(7), 3.

Driver, R., Newton, P., \& Osborne, J. (2000). Establishing the Norms of Scientific Argumentation in Classrooms. Science Education, 84(3), 287-312.

Hake, R. R. (1998). Interactive-engagement versus traditional methods: A six-thousandstudent survey of mechanics test data for introductory physics courses. American Journal of Physics, 66(1), 64-74.

Hake, R. R. (2002). Relationship of individual student normalized learning gains in mechanics with gender, high-school physics, and pretest scores on Mathematics and Spatial Visualization. Physics Education Research Conference, 8, 1-14.

Henderleiter, J., Smart, R., Anderson, J., \& Elian, O. (2001). How do organic chemistry students understand and apply hydrogen bonding? Journal of Chemical Education, $78(8), 1-5$.

Jackson, N. (2004). Developing the concept of metalearning. Innovations in Education and Teaching International, 41(4), 391-403.

Karpicke, J. D., Butler, A. C., \& Roediger, H. L. (2009). Metacognitive strategies in student learning: Do students practise retrieval when they study on their own? Memory, 17(4), 471-479.

Kauchak, D. P., \& Eggen, P. D. (1998). Learning and Teaching: Research-based methods ( $3^{\text {rd }}$ ed.). Boston, MA: Allyn and Bacon.

Keil, F. C. (2006). Explanation and Understanding. Annual Review of Psychology, 25, $227-254$.

Ku, K. Y. L., \& Ho, I. T. (2010). Metacognitive strategies that enhance critical thinking. Metacognition and Learning, 5(3), 251-267.

Marzano, R.J., \& Pickering, D.J. (1997). Dimensions of Learning Teacher's Manual. Colorado: McREL (Mid-continent Regional Educational Laboratory).

McNeill, K.L. \& Krajcik, J. (2006). Supporting Students' Construction of Scientific Explanation through Generic versus Context-Specific Written Scaffolds. Paper presented at the annual meeting of the American Educational Research Association, April, 2006, San Francisco.

Mcneill, K. L., \& Krajcik, J. (2006). Supporting Students' Construction of Scientific 
Explanation through Generic versus Context- Specific Written Scaffolds. Paper Presented at the Annual Meeting of the American Educational Research Association, San Francisco.

McNeill, K. L., \& Krajcik, J. (2008). Scientific Explanations: Characterizing and Evaluating the Effects of Teachers' Instructional Practices on Student Learning. Journal of Research in Science Teaching, 45(1), 533-78.

McREL. (1997). Putnam educational standards and curriculum standards for reasoning the thinking [On-line]. Available: http://putwest.boces.org /StSu/ReasThink.html.

Morgan, G. A., Leech, N. L., Gloeckner, G. W. \& Barrett, K. C. (2004). SPSS for Introductory Statistics: Use and Interpretation (2nd ed.). NJ: Lawrence Erlbaum Associates Inc.

National Research Council (NRC). 2011. A Framework for K-12 Science Education: Practices, Crosscutting Concepts, and Core Ideas. Washington, DC: The National Academic Press.

Osborne, J., Erduran, S., \& Simon, S. (2004). Enhancing the quality of argumentation in school science. Journal of Research in Science Teaching, 41(10), 994-1020.

Osborne, J. F., \& Patterson, A. (2011). Scientific argument and explanation: A necessary distinction? Science Education, 95(4), 627-638.

Pantiwati, Y. (2017). Self and Peer Assessments in Active Learning Model to Increase Metacognitive Awareness and Cognitive Abilities. International Journal of Instruction, 10(104), 185-202.

Paulson, D. R. (1999). Active Learning and Cooperative Learning in the Organic Chemistry Lecture Class. Journal of Chemical Education, 76(8), 1136-1140.

Rahman, S., Yasin, R. M., Salamuddin, N., \& Surat, S. (2014). The use of metacognitive strategies to develop research skills among postgraduate students. Asian Social Science, 10(19), 271-275.

Rahman, S., Yasin, R. M., Jussof, K., Ariffin, S. R., Hayati, N., \& Yusof, S. (2011). The Promotion of Metacognitive Development in the Classroom. World Applied Science Journal. 13 (1): 95-99.

Sadler, T. D. (2004). Informal reasoning regarding socioscientific issues: A critical review of research. Journal of Research in Science Teaching, 41(5), 513-536.

Sandoval, W. A., \& Millwood, K. A. (2005). The Quality of Students â€ ${ }^{\mathrm{TM}}$ Use of Evidence in Written Scientific Explanations The Quality of Students' Use of Evidence in Written Scientific Explanations. Cognition and Instruction, 23(1), 23-55.

Schneider, M., \& Stern, E. (2010). The cognitive perspective on learning: Ten cornerstone findings. In Organisation for Economic Co-operation and Development 
(OECD) (Ed.). The nature of learning: Using research to inspire practice (pp. 69-90). Paris: OECD.

Schraw, G., Crippen, K. J., \& Hartley, K. (2006). Promoting self-regulation in science education: Metacognition as part of a broader perspective on learning. Research in Science Education, 36(1-2), 111-139.

Schrock, J. \& Benko, S. 2015. Using Fundamental Concepts and Essential Question to Promote Critical Thinking. Centre for Engaged Teaching and Learning. http://crte.ucmerced.edu/content/using-fundamental-concepts-and-essential-questionspromote-critical-thinking.

Shannon, S. V. (2008). Using Metacognitive Strategies and Learning Styles to Create Self-Directed Learners. Institute for Learning Styles Journal, 1(2), 14-28.

Smith, K. C., \& Nakhleh, M. B. (2011). University students' conceptions of bonding in melting and dissolving phenomena. Chem. Educ. Res. Pract., 12(4), 398-408.

Sutopo; Waldrip B. (2014). IMPACT OF A Representational Approach On Students' Reasoning And Conceptual Understanding In Learning Mechanics. International Journal of Science and Mathematics Education, 12(4), 741-765.

Tali, L. A., \& Dar, I. A. (2014). Metacognitive Strategy Usage of Primary School Teacher Trainees In Relation To Their Gender. International Journal of English Languege, Literature, and Humanities. 1(V). 157-165.

Wilson, N. S., \& Bai, H. (2010). The relationships and impact of teachers' metacognitive knowledge and pedagogical understandings of metacognition. Metacognition and Learning, 5(3), 269-288.

Winkel, W. S. (2004). Psikologi Pendidikan dan Evaluasi Belajar [Educational Psychology and Learning Evaluation]. Jakarta: PT. Gramedia Pustaka Utama.

Wong, D., Pugh, K., Prawat, R., Jackson, P., Mishra, P., Worthington, V., Thomas, C. (2001). Learning science: A Deweyan perspective. Journal of Research in Science Teaching, 38(3), 317-336.

Yee, M. H., Othman, W., Md Yunos, J., Tee, T. K., Hassan, R., \& Mohamad, M. M. (2011). The Level of Marzano Higher Order Thinking Skills among Technical Education Students. International Journal of Social Science and Humanity 1(2). 121125 .

Yusnaeni; Corebima, A.D.; H. Susilo; Zubaidah, S. (2017). Creative Thinking of Low Academic Student Undergoing Search Solve Create and Share Learning Integrated with Metacognitive Strategy. International Journal of Instruction, 10(2), 245-262.

Zhou, M. \& Brown, D. (2014). Educational Learning Theories. http://creativecommons.org/ licenses/ by/4.0/. 